\title{
Netralitas Aparatur Sipil Negara Pada Pelaksanaan Pemilihan Umum Kepala Daerah Tahun 2020 (Studi di Kabupaten Indragiri Hulu Provinsi Riau)
}

\author{
Ayub Khan \\ Badan Pengembangan Sumber Daya Manusia Povinsi Riau \\ Korespondensi: wijayaabdinegeri@gmil.com
}

\begin{abstract}
Abstrak
Pemilu merupakan salah satu bentuk demokrasi dalam memilih pimpinan. Pelaksanaannya yang secara berkala sudah dijadwalkan di indonesia. Tahun 2020 merupakan jadwal pemilihan serentak di kabupaten kota di provinsi Riau. Dalam hal ini Aparatur Sipil Negara terlibat dalam pemilihan dan juga pelaksana dalam birokrasi pemerintahan. penelitian ini bertujan untuk mengetahui penyebab kurangnya netralitas Aparatur Sipil Negara pada pelaksanaan Pemilihan Umum Kepala Daerah tahun 2020 di kabupaten Indragiri Hulu dengan menggunakan metode penelitian kualitatif, dengan teknik pengumpulan data yang dilakukan menggunakan metode yang umumnya digunakan pada pendekatan kualitatif, yaitu observasi wawancara dengan responden, studi dokumen, analisis data ini dilakukan sepanjang penelitian ini berlangsung. Hasil penelitian menunjukkan bahwa Aparatur Sipil Negara yang ada di kabupaten Bengkalis,Rohil,Rohul dan Kuansing, masih bisa digunakan sebagai alat bagi suatu kekuatan politik tertentu, ini dikarenakan mendapat pengaruh untuk mendukung salah satu pasangan calon, namun mereka tidak berani untuk menyatakan keterlibatannya secara langsung karena takut melanggar peraturan dan mendapat sanksi, serta masih ada upaya dari oknum memasukkan orang-orangnya. Walaupun tidak secara langsung tetapi masyarakat bisa membaca bahwa orang-orang yang dianggap mampu untuk menduduki jabatan. Sedangkan yang dianggap tidak mumpuni di lengserkan atau di nonjobkan.
\end{abstract}

Kata kunci : Netralitas, Aparatur Sipil Negara, Pemilukada.

\begin{abstract}
Election is a form of democracy in choosing leaders. Its implementation is regularly scheduled in Indonesia. 2020 is a schedule for simultaneous elections in city districts in Riau province. In this case the State Civil Apparatus is involved in elections and is also the implementer in the government bureaucracy. This study aims to determine the cause of the lack of neutrality of the State Civil Service in the implementation of the 2020 Regional Head General Election in Indragiri Hulu district by using qualitative research methods, with data collection techniques carried out using methods that are generally used in a qualitative approach, namely observation interviews with respondents, document studies, data analysis was carried out throughout this research. The results showed that the State Civil Apparatus in Bengkalis, Rohil, Rohul and Kuansing districts, could still be used as a tool for a certain political force, this was because they had the influence to support one candidate pair, but they did not dare to express their involvement directly. for fear of breaking the rules and getting sanctions, and there are still efforts from the elements to include the people. Although not directly, the public can read that people are considered capable of holding positions. Meanwhile, those who are deemed inadequate are deposed or discharged.
\end{abstract}

Keywords: Neutrality, State Civil Apparatus, Pemilukada 


\section{PENDAHULUAN}

Komisi Pemilihan Umum (KPU) Riau telah menetapkan daftar pemilihan tetap pemilihan tahun 2020 se Provinsi Riau. Total daftar pemilih tetap di tetapkan 2.458.859 pemilih. Di Provinsi Riau terdiri dari sembilan kabupaten dan kota yang sudah ditetapkan pemilihnya sebanyak 2.458.859 terdiri dari 1.252.185 laki-laki dan 1.206.674 perempuan. Daftar pemilih tersebut tersebar di sembilan kabupaten dan kota yang terdiri dari 116 kecamatan dan 1.290 desa serta 8.356 TPS. Masa kampanye inilah yang berpotensi menyebabkan ASN rentan terhadap pengaruh para calon kepala daerah sehingga profesionalitasnya tergerus. Pemilihan Kepala Daerah (Pilkada) dapat memicu pemanfaatan birokrasi untuk kepentingan politik dalam Pilkada. Di berbagai daerah, calon kepala daerah hampir selalu memobilisasi ASN untuk memenangkan dirinya. Seharusnya birokrasi dibebaskan dari pengaruh dan keterjalinan ikatan politik dengan kekuatan-kekuatan politik, sehingga pelayanan kepada masyarakat yang diberikan oleh birokrasi netral tidak memihak dan obyektif. Birokrasi yang memihak atau tidak netral dapat melahirkan korupsi politik yang justru mengubah proses pilkada diwarnai tindakan-tindakan tidak terpuji. Pemilihan secara langsung bukan hal yang baru dilakukan, sebelumnya juga dilakukan pemilihan secara langsung, perbedaannya mungkin proses pemilihan yang agak berbeda di musim pandemi covid19. Sejak berlakunya Undang-Undang Nomor 32 Tahun 2004 tentang Pemerintah Daerah mulai diberlakukkannya pemilihan secara langsung. Penyelenggaraan Pilkada secara langsung telah membawa perubahan terhadap budaya pemerintahan di tingkat daerah, dalam hal ini reposisi relasi birokrasi dengan politik, khususnya masalah netralitas birokrasi terhadap politik. Pilkada secara langsung dan serentak merupakan situasi yang berbeda, mengingat besarnya kewenangan daerah sejak digulirkannya otonomi daerah. Kepala daerah paling berperan dalam menentukan keberhasilan pembangunan suatu daerah. Dengan kata lain masyarakat lebih banyak berharap kepada kepala daerah dalam memperbaiki kondisi yang telah ada.

Penulis melakukan penelitian mengenai netralitas ASN di Indragiri Hulu Provinsi Riau. Lokasi penelitian ini menarik, karena salah satu kandidat calon kepala daerah adalah Istri dari Bupati Indragiri Hulu, yang di duga akan berpotensi menyebabkan ASN rentan terhadap pengaruh Kepala Daerah sehingga Profesionalitasnya hilang. Netralitas ASN dalam kontestasi politik merupakan kajian hukum kepegawaian. Sebagaimana yang dikemukakan oleh Utrecht, bahwa hukum administrasi menguji hubungan hukum istimewa yang diadakan untuk memungkinkan para pejabat (amsdragers) administrasi negara melakukan tugas mereka yang khusus. Pada satu sisi, ASN adalah aparatur pemerintah yang dituntut melaksanakan tugas pemerintahan untuk memberikan pelayanan publik, sedangkan di sisi lain PNS juga anggota masyarakat yang memiliki kepentingan-kepentingan politis maupun ekonomis yang menyangkut pilihannya dalam Pilkada. Seringkali kepentingan kepentingan tersebut lebih dominan sehingga yang diharapkan sebagai pemilihan yang jujur dan adil tidak terpenuhi.

Di era reformasi salah satu sikap Keputusan Munas ke-5 KORPRI yang merupakan satu-satunya organisasi PNS di luar kedinasan, menyatakan "PNS tidak melibatkan diri dalam kegiatan partai politik". Hampir semua bidang kehidupan diatur oleh peraturan perundang-undangan, melalui penormaan terhadap tingkah laku manusia hukum mencakup hampir semua bidang kehidupan manusia. Termasuk pengaturan dalam Pilkada, terdapat 3 regulasi yang mengatur yaitu Undang-Undang No. 5 Tahun 2014 tentang Aparatur Sipil Negara, Undang-Undang No. 10 Tahun 2016 tentang Pemilihan Gubernur, Bupati dan Walikota dan Peraturan Pemerintah No. 53 Tahun 2010 tentang Disiplin Pegawai Negeri Sipil.9 Pasal 9 ayat (2) Undang-Undang Nomor 5 Tahun 2014 tentang Aparatur Sipil Negara (UU ASN), menentukan bahwa Pegawai ASN harus bebas dari pengaruh dan intervensi semua golongan dan partai politik, sedang Pasal 12 menyatakan Pegawai ASN berperan sebagai perencana, pelaksana, dan pengawas penyelenggaraan tugas umum pemerintahan dan pembangunan nasional melalui pelaksanaan kebijakan dan pelayanan publik yang professional, bebas dari intervensi politik, serta bersih dari praktik korupsi, 
kolusi dan nepotisme. Jika aparat birokrasi pemerintah dapat dijaga netralitasnya dalam pelaksanaan fungsinya, maka rakyat secara keseluruhan dapat terlayani dengan baik dan profesional. Birokrasi yang netral tidak mengutamakan dan memihak kepada salah satu kepentingan kelompok rakyat tertentu. Pemihakan kepada kepentingan seluruh rakyat ini sama dengan melaksanakan demokrasi. Sedangkan keberpihakan birokrasi terhadap salah satu kekuatan partai politik yang sedang memerintah cenderung akan memberikan peluang terhadap suburnya penyalahgunaan kewenangan seperti korupsi, kolusi dan nepotisme. Berdasarkan uraian permasalahan di atas, maka penulis memandang perlu untuk melakukan penelitian mengenai Netralitas Pegawai Negeri Sipil dalam Pemilihan Kepala Daerah.

\section{METODE}

Penelitian menggukakan penelitian kualitatif. Menurut Djam'an Satori dan Aan Komariah (2014) penelitian kualitatif adalah penelitian yang menekankan pada quality atau hal yang terpenting dari sifat suatu barang/jasa. Penelitian dengan menggunkan penelitian kualitatif karena peneliti ingin mengeksplor issue-issue yang terjadi yang tidak bisa di kuantifikasikan yang sifatnya deskriptif . Penelitian ini berfokus pada Netralitas Aparatur Sipil Negara pada Pemilihan Kepala Daerah di Kabupaten Indragiri Hulu.pengkajian sesuai dengan teori Noer, Hamka Hendra (2014) yang mengkaji aspek-aspek Netralitas sehingga fokus penelitiannya adalah: ASN harus netral tidak boleh memihak salah satu calon Kepala Daerah dan tidak boleh menjadi tim sukses calon Kepala Daerah. Responden dalam penelitian ini adalah Aparatur Sipil Negara di Kabupaten Indragiri Hulu.

\section{HASIL DAN PEMBAHASAN}

Netralitas adalah sesuatu yang tidak akan memihak kepada salah satu atau siapapun . Sikap netral inilah yang seharusnya dimiliki oleh semua ASN. Kenetralan ASN bisa dilihat dari perilaku yang tidak ikut serta dalam pemilihan ataupun tim sukses salah satu calon Kepala daerah. Pemilihan umum Kepala daerah selalu jadi perhatian khusus karena ASN walaupun tidak langsung ikut serta dalam partai politik mereka juga mempunya hak memilih dan berpartisipasi dalam pemilihan kepala daerah. Apalagi pemimpin yang terpilih aka memimpin selama jabatan yakni 5 tahun, sehingga kesempatan ini di jadikan alat oleh partai politik agar ASN dapat terlibat. Dari situ dapat diketahui bahwa sedikit banyaknya ASN terlibat dalam pemilihan umum kepala daerah di Kabupaten Inhu 2020. Akan tetapi hal tersebut tidak bisa di pidanakan karena tidak adanya bukti yang cukup untuk membuktikan adanya ketidak netralan ASN di Kabupaten Indragiri Hulu. Permasalahan ketidak netralan ASN jugan menjadi hal yang sangat penting untuk di kaji, walaupun susah untuk pembuktiannya. Terpilihnya Kepala Daerah nantinya akan memimpin dan pelaksananya dilakukan oleh ASN. Disanalah letak hubungan ASN dengan Pemilihan Umum Kepala Daerah. Sehingga para respoden menyimpulkan bahwa ketidak netralan ASN kerap terjadi di Kabupaten Indragiri Hulu. Namun, mereka tidak berani untuk mempengaruhi orang lain atau menjadi anggota partai politik dan tim pemenangan karena takut melanggar peraturan dan mendapat sanksi. Birokrasi ialah tipe organisasi yang digunakan pemerintahan modern untuk melaksanakan berbagai tugas dengan pembagian yang bersifat spesialisasi, dilaksanakan di dalam sistem administrasi khususnya oleh aparatur pemerintah. Arti para pegawai terikat dengan aturan dan di bawah komando pemimpin ataupun kepala organisasi. Pada dasar, perekrutan untuk menjadi seorang ASN dilakukan dengan profesionalitas agar betul-betul mendapat pegawai yang bertanggung jawab terhadap tugas-tugasnya kelak. Menjadi seorang ASN tentu menjadi hal yang membanggakan sekaligus menantang karena tugas tanggung jawabnya berkaitan dengan penyelenggaran pemerintahan yang semuanya dilakukan untuk kesejahteraan 
masyarakat. Dari pendapat-pendapat yang berhasil di peroleh, dapat disimpulkan bahwa pangkat adalah kedudukan yang menunjukkan tingkat seorang PNS berdasarkan jabatannya dalam rangkaian sistem kepegawaian sebagai dasar penggajian. Kenaikan pangkat adalah penghargaan yang diberikan atas prestasi kerja pengabdian PNS terhadap negara. Menurut Kamus Besar Bahasa Indonesia, kenaikan pangkat berarti tindakan resmi dalam administrasi kepegawaian yang mengakibatkan perubahan pangkat Pegawai Negeri Sipil, yakni pangkatnya menjadi lebih tinggi dari pangkatnya semula. Seorang Pengawai Negeri Sipil ataupun ASN akan menerima kenaikan pangkat jika telah memenuhi syarat tertentu sesuai dengan jabatan dan pangkat masing-masing ASN. Hal tersebut diatur dalam Peraturan Pemerintah Nomor 99 Tahun 2000 tentang Kenaikan Pangkat Pegawai Negeri Sipil. Pelayanan kepada masyarakat merupakan salah satu bentuk kerja ASN yang langsung dirasakan oleh masyarakat, sehingga pelayanan yang maksimal dari para pemberi pelayanan ini akan sangat memuaskan kebutuhan masyarakat. Ada beberapa faktor yang dapat mempengaruhi Ketidak netralan ASN dalam pemilihan Kepala Daerah Di Kabupaten Indragiri Hulu yaitu:

a. Mendapatkan atau mempertahankan Jabatan

Kepala Daerah adalah pimpinan yang mempunyai kewenangan untuk mempromosikan jabatan dan memutasikan ASN. Sehingga hal tersebut membuat ASN menjadi dilema atau serba salah. Di satu sisi ASN harus netral sedangkan di sisi lain para ASN juga mempertahankan Jabatan yang sudah diberikan oleh kepala daerah tersebut.

b. Adanya hubungan kekeluargaan

Ketidak netralan ASN juga di picu oleh adanya hubungan kekeluargaan. Yang selama menjabat mereka memberikan jabatan kepada keluarga ataupun teman dekat sehingga merekan akan mempertahankan pimpinan demi jabatan yang didapat.

c. Ketidakpahaman terhadap peraturan tentang Netralisasi ASN

Masih banyak ASN yang tidak dapat memahami peraturan tentang Netralisasi ASN. Sebagian mereka memahami akan tetapi lebih memilih melanggar peraturan tersebut demi mempertahankan Jabatan.

d. Faktor lain adalah tekanan dari atasan, anggapan bahwa ketidaknetralan ASN tidak diberi hukuman yang menimbulkan efek jera.

Untuk meningkatkan netralisasi ASN ada beberapa upaya yang harus dilakukan diantanya adalah pemantauan secara langsung maupun tidak langsung.

Pemantauan secara langsung dilakukan dengan cara memantau pada saat kegiatan kampanye berlangsung. Apakah ada ASN yang terlibat secara langsung dalam kampanye tersebut. Selain itu juga dilakukannya pemantauan secara langsung dilingkungan Asn apakan ada perilaku untuk membujuk atau mengajak masyarakat sekitar untuk memilih pasangan calon pemerintah daerah, jika ada langsung di dokumentasikan berupa foto atau video sebagai barang bukti.

Pemantauan secara tidak langsung dilakukan dengan cara memantau percakapan ASN di grup messenger ataupun dalam postingan media sosial, dan juga meminta bantuan kepada masyarakat yang memiliki bukti bisa langsung melaporkan melalui www.lapor.go.id .

Untuk selanjutnya bisa juga dengan cara meningkatkan pemahaman ASN mengenai Netralisasi ASN dan juga sanksi-sanki yang bakal diterima oleh ASN jika melanggar peraturan tersebut. Cara meningkatkan pemahaman bisa melalui sosialisasi secara langsung ataupun dengan cara memberikan brosur mengenai netralisasi kepada ASN, Bisa di berikan kekantor-kantor, sekolah, tempat-tempat kesehatan yang ada kaitannya dengan ASN.

Untuk selanjutnya penindakan netralisasi ASN, Badan Pengawas Pemilu (Bawaslu) bertugas untuk meningkatkan pemilu menjadi berkualitas sehingga mendapatkan hasil pemilu secara langsung,bebas, rahasia, jujur dan adil. Dengan demikian maka bawaslu berperan penting dalam berlangsungnya pemilu. 
Penindakan yang dilakukan kepada ASN yang melanggar netralisasi di tangani sesuia dengan SOP yang telah di tetapkan. Supaya tidak terulang kembali kejadian yang sama.

\section{KESIMPULAN}

1. ASN Kabupaten Inhu seringkali mendapat pengaruh baik secara langsung maupun tidak langsung dalam pemilihan kepala daerah. Akan tetapi mereka tidak mengungkapkan keterlibatan mereka dikarena mereka takut melanggar peraturan sehingga dikenakan sanksi.

2. Masih adanya pengaruh pimpinan terhadap posisi jabatan yang diberikan sesuai dengan kubutuhan pimpinan. Dan menganti orang-orang yang dianggap tridak sejalan dengan pimpinan.

3. Praktek politik dalam birokrasi masih terus terjadi, ada ASN yang secara diam-diam mendukung dan menggerakkan massa agar ketika pasangan calon tersebut terpilih mendapat jabatan penting dalam suatu instansi. Sedangkan untuk ASN yang tidak mendukung pasangan calon yang terpilih diberikan sanksi berupa nonjob. Hal tersebut secara tegas menjelaskan bahwa ASN masih kurang netral dan banyak terpengaruh oleh partai politik, terlebih khusus partai politik yang berkuasa.

\section{DAFTAR PUSTAKA}

[1] Asshidiqie, Jimly, 2009. Pengantar Ilmu Hukum Tata Negara, Jakarta : Raja Grafindo Persada.

[2] Aan Komariah, Djam’an Satori. 2014 Metodologi Penelitian Kualitatif. Bandung : Alfabeta.

[3] Efendi, sofian 2018.Pengawasan Netralitas Aparatur Sipil Negara. ISBN 978-602-53106-1-4 “

[4] Irtanto. (2008). Dinamika Politik Lokal Era Otonomi Daerah. Yogyakarta: Pustaka Pelajar

[5] Muh. Amin, La Ode. 2013. Netralitas birokrat pemerintahan pada Dinas Pendidikan Kota Makassar dalam pemilukada di kota makassar (pemilihan Walikota Makassar tahun 2008). Makassar dalam http://103.195.142.17/handle/123456789/6824

[6] Mokhsen, Nuraida 2018. FGD Sistem Pengawasan KASN Terhadap Pelaksanaan Asas Netralitas ASN, Jakarta 21 Mei 2018

[7] Thoha, Miftah. 2007. Birokrasi dan Politik di Indonesia. Jakarta: Rajawali Press.

[8] Noer, Hamka Hendra. 2014. Ketidaknetralan Birokrasi Indonesia, Studi Zaman Orde Baru Sampai Orde Reformasi. Jakarta : Gramedia

[9] Prasojo, Eko. FGD Sistem Pengawasan KASN Terhadap Pelaksanaan Asas Netralitas ASN, Jakarta 21 Mei 2018

[10] Rina, Martini 2015. Netralisasi Birokrasi Pada Pilgub Jateng 2013.Jurnal Ilmu Sosial Vol.14 no.1 februari 2015 
[11] Sri Hartini, Penegakan Hukum Netralitas Pegawai Negeri Sipil (PNS), Jurnal Dinamika Hukum Vol. 9, No. 3 (2009) Publisher; bahan ini diambil dari Watunglawar, Matias Neis Dalam Perwujudan Asas Netralitas Birokrasi Dalam UU Nomor 5Tahun 2014 Tentang ASN, Jember (2015)

[12] Tricahyo, Ibnu,2009. Reformasi Pemilu Menuju Pemisahan Pemilu Nasional dan Lokal, Malang : InTrans Publishing.

[13] Utrecht. 1962. Pengantar Hukum Administrasi Negara Indonesia. Jakarta: Ichtiar.

[14] Undang-undang Nomor 5 Tahun 2014 tentang “Aparatur Sipil Negara”

[15] Undang Undang No 10 Tahun 2016 Tentang Perubahan kedua atas Undang Undang Nomor 1 Tahun 2015 Tentang Penetapan Peraturan Pemerintah Pengganti

[16] Peraturan Pemerintah Nomor 37 Tahun 2004 tentang Larangan Pegawai Negeri Sipil menjadi Anggota Partai Politik

[17] Undang-Undang Nomor 23 Tahun 2014 Tentang Pemerintahan Daerah.

[18] Peraturan Pemerintah Nomor 11 Tahun 2017 yunto Peraturan Pemerintah Nomor 17 Tahun 2020 Tentang Manajemen Pegawai Negeri Sipil. 